\title{
DE VREDE.
}

Destijds, terstond na het uitbreken van den werelldoorlog, welke thans in liquidatie is, heb ik in dit tijdschrift getracht de economische beteekenis daarran te schetsen, door de hoofd-kenmerken, welke aan iederen oorlogi eigen zijn, in het licht te stellen. Met hetrekking tot den vreidie moet een dergelijk streven falen.

Oorlog is oorlog, de opperste inspanning der volken, cile hem roeren, ter lereiking van de doeleinden waarvoor hij door hen is annraard. Maar de heteckenis van den vrede hangt seheel af van den inhoud der vonrwarden, waarop hij wordt gesloten. Oorlog beteekent wijziging in de richting; waarin het volk, dat hem roert, tot dusver zijln prodluctieve krachten aanwendide en geweldige uitzetting van het verbruik, toenemenlde bevrediging van behoerten in het heden ten koste van die der toekomst. Men zou echter zich volkomen veryissen, walnneer men mocht meenen, dat de thans tusschen de geallieerdie mogendhedien en Duitschland gesloten vrede bij de vroegere helligerenten terstond, eene, aan de roegere actie evenredige, reactie der productieve energie in de richting van den vredesarbeid, en, een sterke inperking van het direct rerbruik ten gunste der besparing zoude hebben teweeggebracht. Zeker, de beschikbare bevredigingsmidddelen zijn allerwege, en met name in Duitschland, zóó beperkt, clat vrijwillige bezuiniging en besparing wel uiterst rezwaarlik moet wezen. Maar toch stemmen alle berichten hierin overeen, dat eer een geest van roekelooze onbekommerdheid, van opmaken wat er nog is, dan een van zor ̧zaam overleg de houding d'er bevolkingen kenmerkt. Van een krachtig weder hervatten van dien viredesarbeid, of ook maar van georganiseerdie vooribereiding om daartoe te geraken, is, in Europa althans, weini, of niets te bespeturen. Veeleer is een geest van verwildering, van ontbinding, in de bevolkingen gevaren. Het streven is er op gericht, om uit den faillieten boediel zooveel mogelijk te eigen profijte machtig te worden, niet om door een bezieldl aanpakken van het werk van herstel, het welk ook daar, waar de oorlog niet rechtstreeks woed dè, dringend om uitvoering roept, de zoo jammerlijk gesohokte volkswelvaart wedier op te heffen. 
Nergens openibaart zich het gevoel van psychische bevrijding, dat men na deze bange ooriogsjaren zou heb ben mogen verwakhten. Bij de overwonnenen is cilt uit die bittere ontgoocheling, door dezen afloop van den ourlog gewelst, en uit de offers welke ter wille van den vrede moesten worden aanvard, begrijpeli.k. Bij de overwinnaars .zal het toenemerci inzicht in het feit, dat, met quitzondering ran de Ver. Staten en Japan, het eigen economisch leven is untwricht in een mate, welke lange jaren van inzinking muet deen. duchtex, en rooral het besef van de onmogelijkheid om aanstondls ran de volkomen uitgeputte centrale riken de roor de naaste toeliomst reeds gehoopte belangrijke bijdragen voor den wederopbouw te verkrijgen, de geestelijke depressie. welke ook daar zich steeds meer afteckient, litunnen rerklaren. Mara ook bij de weinige neutralen, die, in vergeljping tot die ontlogroerende mogendheden, in ree] geringere mate de gevolgen van den oorlo lyebinen te verduren geluad, is van een blikde ontspanning na het herstel van den viede weinig of niets te bespeuren.

De verklaring geeft d. m. eenerzi ds, roor wat de neut tralen betreft, cle afloop ran cien oorlog, anderzijicls, in meer algemeenen, zin ${ }_{x}$ de inhould van den vrede.

Wat den alloop ran den oorlog betreft, het is hier niet de plaats om op de politielse beteekenis daarvan uitroerig in te ga:m. Doch het schijnt mij niet twifelachisio dat, voor de neutralen in het algemeen en roor Nedlerland in het bijonder, een afloop van den oorlog, welke in een erenwichtsrrecle haar rezegeling zoude hebben verkregen, verre verkieseli is ware : eweest boven dezen, welke de neutralen rrijwel reheel afhankeliik maakt van die geallieerde staten, die tijdens clen borlog het gansche bedrijifleren der netitralen aan stage, scherpe controle hebiben ondierworpen; een afloop hovendien welke ons economisch achterland, waarvan de oploci ook aan ons in zoo hooge mate is ten goede gekomen, indien de bedoelingen der orerwinnass worden rerwezenlikt, in afzienbare toekomst zich nauwelijks toren het peil van economischen ondergang zal kunnen doen verheffen.

Intusschen, de belangen ran de neutrailen, die hum positie, met de goede en kwade kansen. welle ziji medie brachit, zelf hieblen gekozen, en die dankhar mogen zijn, dat zijl althans voor de onnoemel"ke ellende ran deelneming aan dien oorlog zijn bewaard gebleven, hebben uiteraard in die raaldkamer der overwinnaars geen cewicht gelegd in die schaal. Bood de vrede, welke thans gesloten werd, uitzicht op duurzaamiheid, op een geleidieliken oroei van een statengemeenschap welke in eerlijken economischen 
wedijver de rerwezenlijking van algemeene welvaart encultuur-ontwikkeling nastreefcle, dan zouclen de neutralen zich over den afloop van den wereicloorlog niet mogen beklagen. Doch aan dit uitzicht ontbreekt letterlijk alles.

De toestand dour dien vrede soschinen kitn niet cruurzaam zijn. Een gebalkaniseerci Midden- en Oost-Europa zal onvermijdelijk in gisting en onrust hlijven verkeeren. Het Duitsche volk, in Europa ontwijfeltaar het meest vitale op schier jeder gebied, kan zich niet blijvend neerieggen bij den vrede van Versailles, waaronder het gedworgen werd zijth hamdteekening te plaatsen. Het geroel ran saamboorigheid, hetwelk, in en na de voremper-revolutie meer nog dan. tijdens clen oorlog zelf, glansrijk de vuurproef doorstond, zal de Duitschers onvermijcleli $k$ doen zinnen op hereeniging ran wat niet clutrzaam gescheiclen kan worden. Frankrijk, clat op een mannelijke bewolking tusschen 15 en 4i) jaar ter sterlite (rolgens de jongste vorikstelling van 5 Maart 1911) ian 8.8 milliven zielen, aar clooden 1.3 mill. rerloor, terwijl 2.6 mill. strijclers gewond werdten, de sterfte onder die thuisgeblevenen hocger was clan de normale, en de aanyullin: door gebonten verre benedien het reeds voor den oorlog lage peil bleef, mist reeds chemplogisch de kracht om, als eenige wezenligk groote mogendheid ran Europa's raste land, den toestand, welke het daar, dank zij den steun ran zóvele iondgenocten, van de Engelsehen bovenal, seschapen heeft, hlijvend te beheerschen. Te meer wijl het, econcmisch aan den rand van clen afgrond, zich. nu de zaak zóó liep, riet zal vermogen te bevrijden van die dirukkende militaire lasten. Zóó weinig gerust roelt het zich, ra de onderteekening van een vrediesverdrag, hetwelk in zekeren zin een doorloopende betuiging van hulde aan de geweldige kracht ran het Duissche rolk zou kunner? wordien genoemd, en zóó weinig vertrouwt het op het zoogenaamd Volkerenrerbond, dat het aanstonds daarnaast met zijn twee machtigste bondgenooten van heder te eigen behoeve een diefensief verbond heeft gesloten. Maar is het aan te nemen, dat cle gruote belangen-rerschillen, welke, de eeuwen door, tusschen Frankritk en Engeland, met name op koloniaal gebied, hebben bestaan, nu roorgoed tot het verledien zullen rehooren, en zulks nog wel in een tijd waarin Frankrijk nog mindier dan vóor den oorlog de midldelen zad hebren, om zijn immens hezit in andere werelddeelen wezenlit $k$ te kolontiseeren en tot economischen bloei te brengen? En indien het bondyenootschap met Engeland dientengevolge eerlang aan innigheid verliest, welke zal dan, tegen dien achtergrond van dezen vrede, de positie van Frankrijk zijh? Frankrijk, dat een 
.eeuw geleden door de vereenigde inspanning van machtige tegenstanders moest worden hedwongen, werdithans door de hulp zijner bondyenooten nog staande gehouden. Verstandig zoude het d.m. hebben gehandeld, indien het, niet verblind door de dapperheid waarmede ook zijn legers hebben gestreden, er van had algezien eenen vrede te verlangen, wellis handhaving ciie hulp blijvend tot voorwaarde heeft. Het ware niet onmogelijk, dat ten? slotte deze vrede, geinspireerd door een grijsard, vans wien men heeft gezegd, dat hij nog slechts verleden, geen toekomst meer kent, Jater zal blijken finem Galliae, niet, zooals roogd werd, finem Germaniae te hebten ingeleid, en Frankrijk terug zal dringen in den rang van een mogendheid als Spanje.

Doch naast politieke, is het niet minder economische kortzichtigheid, wejke in het rredesverclrag pijnlijk treft. Het is eigenlijk meer een voortzetting vam den oorlog met andere midile!en dan een rredesvendnag. De oorlog heette $0 . m$. te worden geroerd ter vernietiging ran het zoogrenaamde Duitsche militairisme. De vreale heeft echiter het Duitsche rolk, roor zooveel het clit nog niet wist, geleerd, wat een weerloos Duitschlarid te wachten staat, en is daardoor metterdand de krachtigst denkbare prapaganda roor het herstel ran Dutgihiands weermachi seworden. Volkcmen uitgeput uit den strijd komend, hadi Europa bovenal er tehoffte aan, dat aan zijn volken, verlost ran den druk der hewapening, den weg werd gewezen om door harden arbeid het jammerlijk gedaaldi welvaartspeil weder op te roeren. Tnzonderheid in het Duitsche volk, dat tot enorme schadeloosstellingen moest worden gedwongen, harl de lust c.m aan het werk te gaan, teneinde allereerst die rergoedingen af te lietalen en daarna geleidielijk zich er weder bovenop te werken, moeten worden gewelst. De bekrompen mercantilistische opvatting, als zoude de welraart ran den een slechts ten koste ran die ran den andier bereiktaar zijn, had plaats moeten maken voor het juiste inzicht, dat in die economische wereld het eene groote rolk niet lijden kan, zonder dat alle overigen daarvan den weerslag ervaren omgekeerd ook de bloei van den een, allen overigen mede ten goedie komt. Het beginsel vas den vrijhandiel had behooren te worden aanvaard, hetwelk allen gel ke kansen biedt, om zich zoodani, en afzet te veroverer, als waarop zij raar die mate van hun wezenlicke kracht en be. kwaamheid aanspraak kunnen doen geldien, en dat, de staten niet langer als gesloten economische eenheden met strijdige belangen tegenover elkaar plaatsend, aan alle imperialisme den grondslag zou hebten ontnomen, de 
burgers van alle staten overal rrijelijk zoucle hebben doen concurreeren, d.w.z. doen wedjjreren om eikaar over en weer diensten te mogen bewijzen. Hierin immers bestaat welleschouwd het wezen zelf der mededan?ing.

Ware het rredesterdragl, door deze beginselen gedragen geweest, dar, had het den Duitschers een uitzicht op mogelijken herbouw wn? hun rernietigden welstandigeopend? en een prikkel gegeven om terstond met kracht de hand te slaan aan den ploeg, teneinde de toekomst, waarin dit uitzicht zoude verwezenliilit zijn, zoo snel mogeliki te dioen intredien. Tegenover de verwildering, droor den oorlog te weeggebracht en door de revolutie bevorderd, ware dan de mogelijkheid voot een organisch herstel gegeven. En de zeest, welke daw in het vrediestierdrag zoudie heblen doorostraald, zou niet hebben nagelaten ook op de levolkingen der veassocieerde rijken gunstig in te werken. Zij zoulden gewezen ziin op de onmisbaarheid ran internationale samenwerkin:; ter verhooging van het ejgen welrartspeil, ook met een zoo krachtig economisch geheel, als het door uithongering tot capitulatie gedwongen Duritschland. $\mathrm{Zij}$ zour den, in réél meerder mate dan thans mogelijk zal blijken, zich den zwaren last der bewapeningen van de schouders hebben kunnen werpen, en tegen het ontzettend gevaar dier besmetting met het bolsjewisme in Duitschiland den krachitigsten beschermer hebben gehad, instede van het thans roortdurend ran de andere zijde van den Rijo te zien dreigen.

Doch: het verdrag, gelijk het door Duitschland moest wordlen aanvaard, aclemt niet een geest ran verzoening, doch ran haat en ran wrakk, denzelfdien reest die Lloyd George, ondier toejuiching van "the molv", aan het Engelsche publiek die walgelijke sensatie ran een proces tegen den crewezen Keizer deed in uitzicht stellen. Het dwingt Duitschland tot een jarenlangen slavenarbeid ten hehoeve en ondier controle zïner vijanden, schakelt het overigens vriiwel rolkomen uit het international verkeer uit, en plant in den Duitschen volksqeest het qeroel ran wrok en de zucht naar revanche.

Men noemt den geest van het vredesverdrag begrijpeliik, nu de oorlog op het grondgebied van de orerwinnaars is gevoerd en hum, in plaats ran den overwonnene. de ontzettende retwoesting heeft doen ondergaan, welke een moderne nurlog onvermijdeliik met zich hrengt. Het moge zon ziir, al ware hel weinig troostvol, dat de geroelens van haat wèl, die van verzoenins niet begrijpelijk zouden moeten heeten. Maar zeker dunkt 
het mij, dat deze rrede het economisch horstel van de gevolgen van den oorlog uitcmate zal blidien te bemoeilijken, en cie heerschencle orrust en onzekerheid in Europa gediurende langen tid zal bestendligen. Dit verklaart, naar het mii vorkomt, de luste'oosheid, welke ondanks het teekenen ran ran den rrede, heerschen bliyt. in aanzienli ke mate.

Duurzaam kin de vrede van Versajlles niet zijn. Mẹn kan slechts hopen, dat de volken eerlang rrijwil ig. de noodzalielijkheid eener grondige herziening zullen erkennen, onder den druk der arbeiders, die in bloed en in goed het zwaarste deel der lasten, zoowel ran een blijvende ontust, als ran een hernieuwden wapengarg, zouden te drawen herter. Zoo niel, ban zal deze lalatste op den duur onvermijclelijk blijken, en de thans reeds zoo diep weschokte wehaart an con nuw reel rerder gande bedreiging zijn hlontgesteicl.

$$
\text { C. A. Verrijnstuart. }
$$

Ltrecht, i Juli 1919. 